\title{
Phytophthora root rot: its impact in botanic gardens and on threatened species conservation
}

\author{
Brett A. Summerell' \& Edward C.Y. Liew ${ }^{2}$
}

\begin{abstract}
Phytophthora root rot is one of the most devastating diseases of perennial plants worldwide, affecting plants in food production, amenity plantings and in natural ecosystems. The impact of these diseases in botanic gardens can be substantial and can affect how a site may be used for months and years ahead. Management is critically dependent on avoidance of the introduction of the pathogen and effective hygiene protocols are key to achieving this. Additionally, botanic gardens have a key role to play in protecting plants and enhancing conservation outcomes through surveillance, education and ex situ conservation programmes, as well as through the recognition that they can be critical as sentinel sites to detect new incursions of pests and diseases. The impact of several Phytophthora species on the in situ and ex situ management of the critically endangered Wollemia nobilis (Wollemi pine), which is highly susceptible to phytophthora root rot, is used to highlight the need to ensure management of these pathogens is a critical component of threatened species recovery and management.
\end{abstract}

\section{Introduction}

Phytophthora (Stramenopiles: Oomycetes: Peronosporales) is an oomycete genus of plant pathogens that are notorious for causing a range of plant diseases in agriculture, horticulture and natural ecosystems. The most well-known and economically important species is Phytophthora infestans, the cause of late blight of potato and partially responsible for the potato famines that devastated Ireland in the 18th century. It is, however, the root-attacking and soil-borne species that cause issues to amenity plantings, including those in botanic gardens, and that can impact how an area will be cultivated and what plant species can be grown for years, even decades later.

\section{Phytophthora root rot}

Within the genus Phytophthora there are a large number of described species, the majority of which are associated with diseases of food crops (Erwin \& Ribeiro, 1996). The origin of most of these species was unknown, but many have been distributed globally with their hosts. Many of these species are often associated with diseases of perennial plants, in natural ecosystems and sometimes in horticultural and amenity plantings. There have been numerous new species of Phytophthora described from many parts of

\footnotetext{
${ }^{1}$ Brett Summerell is Director of Research and Chief Botanist at the Royal Botanic Gardens and Domain Trust. Address: Australian Institute of Botanical Science, Royal Botanic Gardens and Domain Trust, Mrs Macquaries Rd, Sydney, New South Wales 2000, Australia. 
the world; in 1996, 50 species of Phytophthora were known to science and in the subsequent 22 years more than 100 new species have been described or designated (e.g. Burgess et al., 2018).

Many of the most destructive species of Phytophthora cause phytophthora root rot, a disease of trees, shrubs and herbaceous plants (Erwin \& Ribeiro, 1996; Burgess et al., 2017). It has been estimated that 66 per cent of rots of fine roots and 90 per cent of collar rots in perennial plants are caused by Phytophthora species (Tsao, 1990). Phytophthora cinnamomi is an aggressive pathogen of trees and shrubs that has for a long time been recognised as an important problem affecting some plantation crops (especially avocados), ornamental species and many Australian native species, causing significant widespread losses in native vegetation in those parts of Australia where the average annual rainfall is greater than 600 mm per annum (Irwin et al., 1995; Podger \& Brown, 1989; Pratt \& Heather, 1973; Shearer \& Tippett, 1989; Burgess et al., 2017). With such a broad host range this species has become important in the management of botanic gardens and in their efforts to conserve plants in both ex situ and in situ conservation programmes. Worldwide it is one of the most important plant pathogens and has been listed by the Global Invasive Species Database $^{3}$ as one of the 100 worst invasive alien species (Burgess et al., 2016).

Many of these diseases have long been issues in horticulture, but less recognised in natural ecosystems and amenity horticulture. For example, Phytophthora cinnamomi was first recorded in Australia from pineapple in 1929 but not recovered from native vegetation until 1948 (Gerrettson-Cornell,
1986; Irwin et al., 1995; Weste, 1994). For many decades there was contention about the origin of this pathogen with two views; firstly that the pathogen was introduced and secondly that it was indigenous to Australia, or at least some parts of Australia (Pratt \& Heather, 1973; Weste, 1994). This latter viewpoint was based on, firstly, recovery of the pathogen from remote sites where, it was argued, it was unlikely that the pathogen had been introduced to; and secondly, the relative resistance of plant species in eastern Australia to the disease (Cho, 1983; McCredie et al., 1985). However, it has now clearly been shown using a range of population and molecular analyses that there is limited genetic variation and a skewed population ratio that is only consistent with the pathogen being introduced into the country from elsewhere (Dudzinski et al., 1993). Recent research has documented the existence of a number of native species of Phytophthora in native vegetation in Australia (Scott et al., 2009; Burgess et al., 2017). Many of these species are cryptic and difficult to differentiate from better known species of Phytophthora but also appear to be less important plant pathogens causing limited disease issues (Scott et al., 2009; Burgess et al., 2017).

Global analyses of Phytophthora cinnamomi have shown that its centre of origin is in highland regions of Southeast Asia (Arentz \& Simpson, 1986; Martin \& Coffey, 2012), and that it is likely to have been introduced into Australia through the importation of plant material for horticulture in the early days of the fledgling colony from the then Dutch East Indies. Regardless of this, the pathogen has been widely spread since then through human-mediated means and, as a consequence, is now found in most

\footnotetext{
${ }^{3}$ See http://www.issg.org
} 
states of Australia where the environmental conditions will allow it to survive (Burgess et al., 2017). These factors have important implications with respect to management of these diseases and the efforts put into preventing the movement of the pathogen. If a pathogen is clearly defined as exotic and with a restricted distribution then there is a view that efforts to prevent infection are warranted and worthwhile.

The impact of the disease can be quite variable depending on the susceptibility of the vegetation, environmental conditions and soil type (Figs $1 \& 2$ ). For example, in Western Australia, Jarrah dieback is a disease syndrome caused by this pathogen where large vegetation communities dominated by jarrah (Eucalyptus marginata) can be devastated (Shearer \& Tippett, 1989;

McDougall et al., 2002). In contrast, the impact of Phytophthora cinnamomi on native vegetation in eastern Australia is less dramatic and certainly it does not appear to cause the widespread vegetation losses that are observed in southern and western Australia. However, recent research has shown that $P$. cinnamomi plays an important role in dieback of a number of vegetation communities found in eastern Australia (McDougall \& Summerell, 2003; McDougall et al., 2003; Puno et al., 2015; Scarlett et al., 2015).

\section{Phytophthora biology}

Phytophthora species are predominantly soil-borne pathogens whose active inocula - zoospores - swim through soil towards

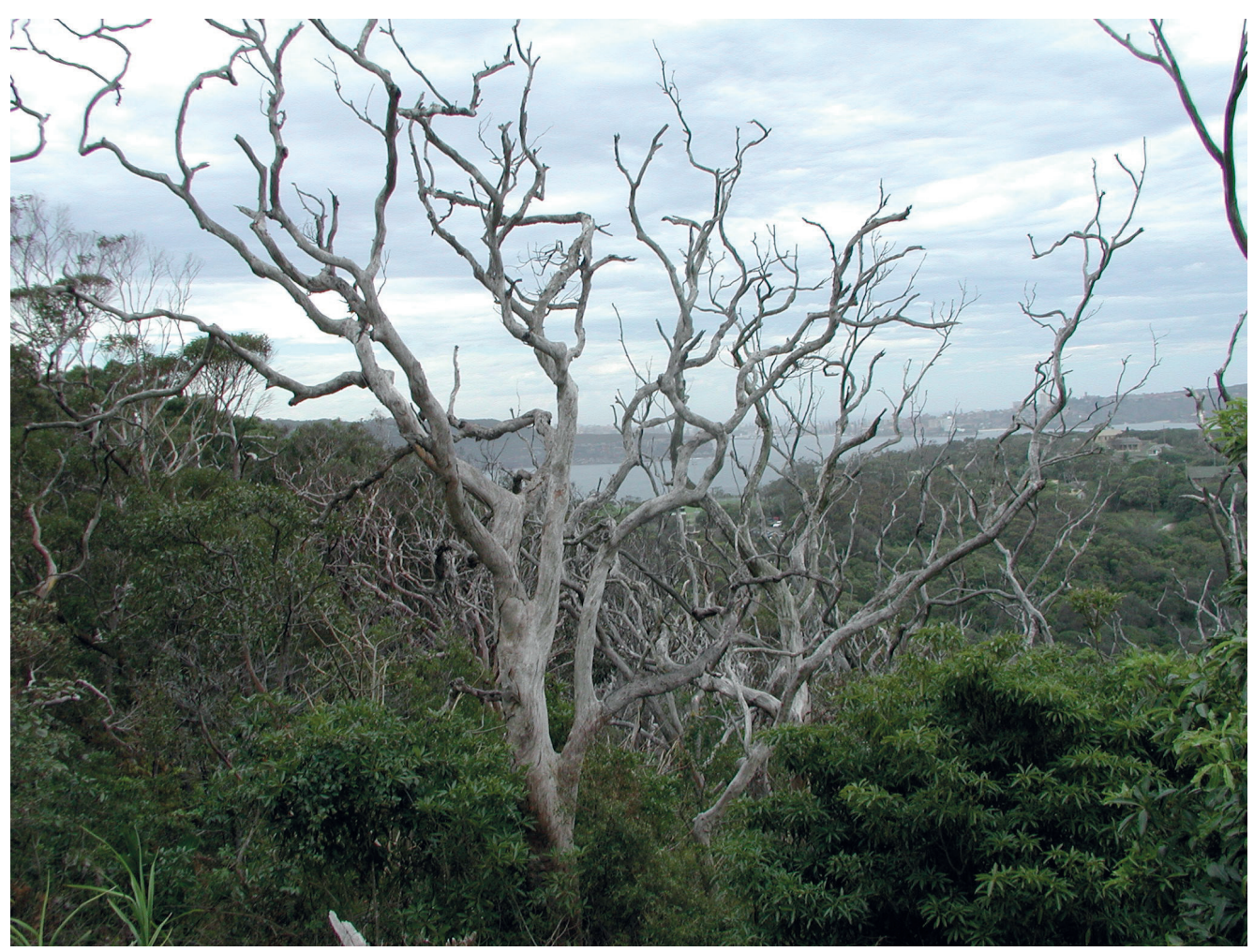

Fig. 1 The impact of Phytophthora cinnamomi causing dieback of Angophora costata and Eucalyptus botryoides at Middle Head overlooking Sydney Harbour. Photo: Brett Summerell, Royal Botanic Gardens and Domain Trust. 


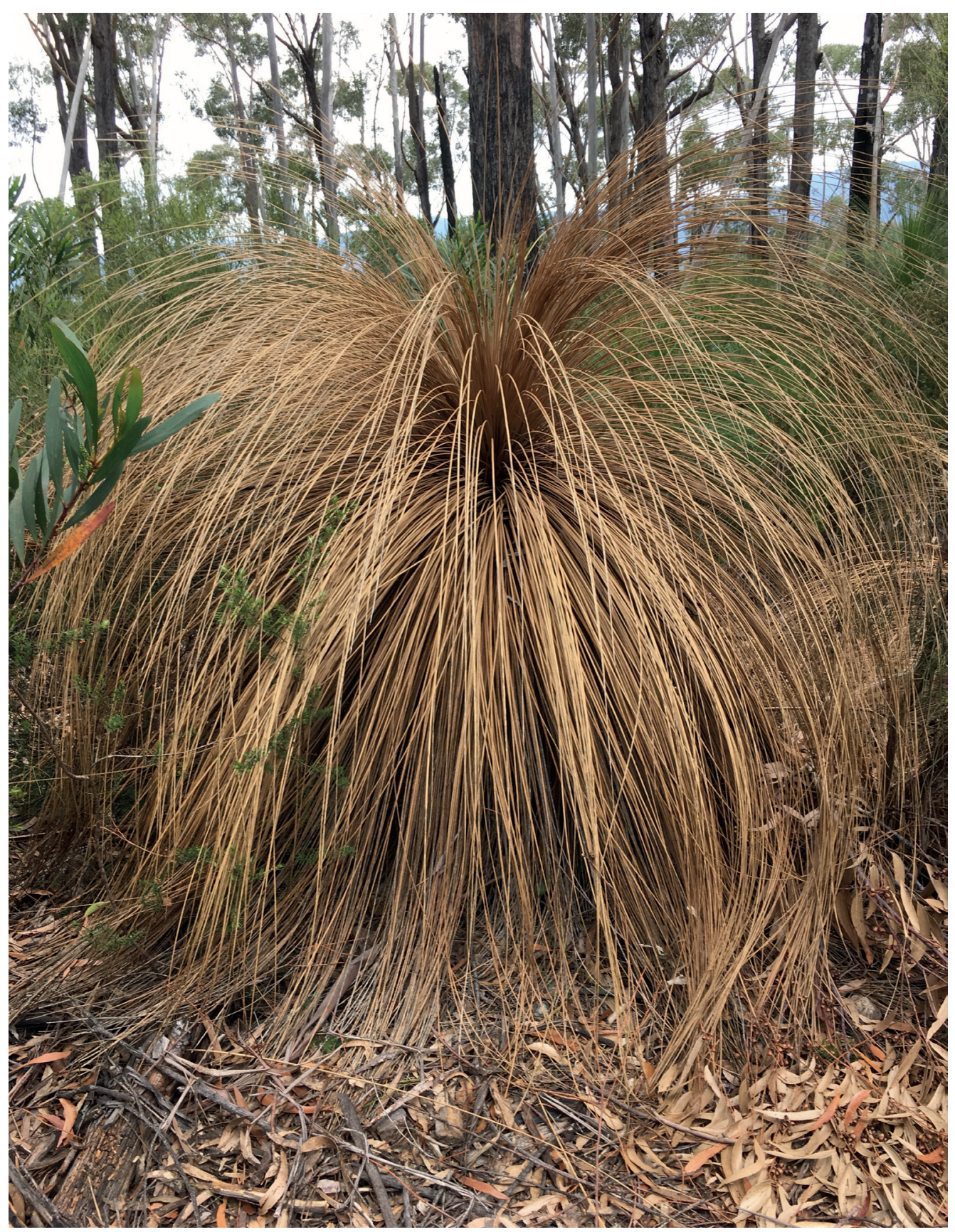

Fig. 2 A grass tree, Xanthorrhoea spp., affected by phytophthora root rot caused by Phytophthora cinnamomi at South East Forest National Park, New South Wales, Australia. Photo: Brett Summerell, Royal Botanic Gardens and Domain Trust.

the roots of plants and need high moisture levels to move to and infect a root system (Figs 3 \& 4). Once roots are infected, mycelium grows through the root, destroying cells and preventing the root from extracting moisture or nutrients from the soil (Erwin \& Ribiero, 1996). The pathogen can survive in soil for extended periods by specialised 
survival structures such as oospores and chlamydospores - as a result, once soil has been infested it can be expected to remain that way for considerable periods of time (Weste \& Vithanage, 1979).

\section{Phytophthora can be moved to and} spread to new sites via infected plant material and infested soil, which may adhere to equipment, boots and tyres, and be transmitted through drainage water. As a consequence it can spread through native vegetation. Infested soil adhering to tyres and machinery can easily spread considerable distances, and activities like road construction, logging and mining have dispersed the pathogen over vast tracts of land in many regions of Australia. A critical component of the control of the spread of this pathogen has been communication programmes to promote hygiene practices in order to ensure that horticultural staff, visitors and the like do not have soil adhering to their boots and equipment before stepping in a garden bed and that they avoid muddy areas, stay on paths and follow any directions regarding this pathogen. The impact of the disease can be quite variable depending on the susceptibility of the plant species, environmental conditions and soil type.

Symptoms of the disease include chlorosis (yellowing of foliage), wilting and dieback, and infected plants can die very rapidly if stressed by reduced water availability (Erwin \& Ribiero, 1996). Diagnosis can be difficult, since the symptoms can be confused with nutrient and water stress and other diseases and pest problems. In very susceptible species the impact can be rapid and severe. These species will have extensive root death and the pathogen can extend into the crown - in these circumstances the plant will rapidly die. When the first symptoms of phytophthora root rot become evident in

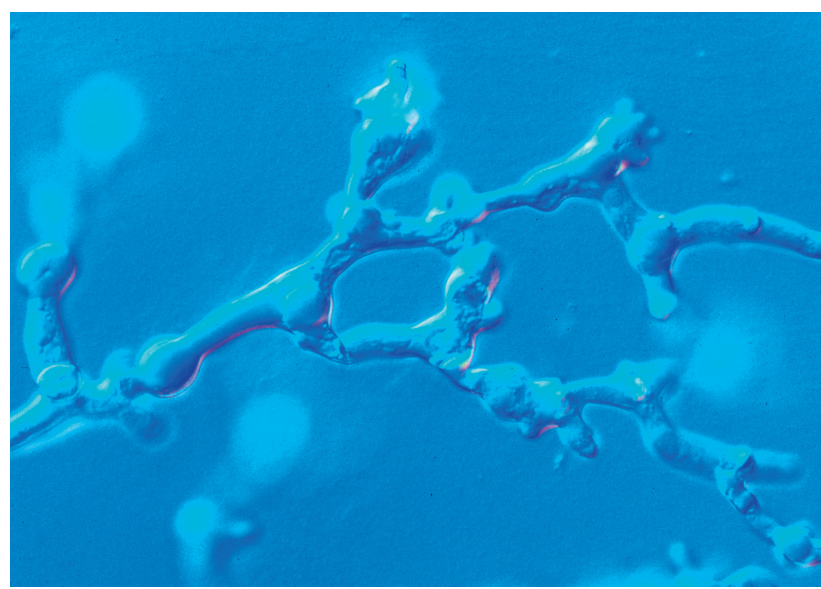

Fig. 3 Hyphae of Phytophthora cinnamomi (100x magnification). Photo: Ratiya Pongpisutta, Royal Botanic Gardens and Domain Trust.

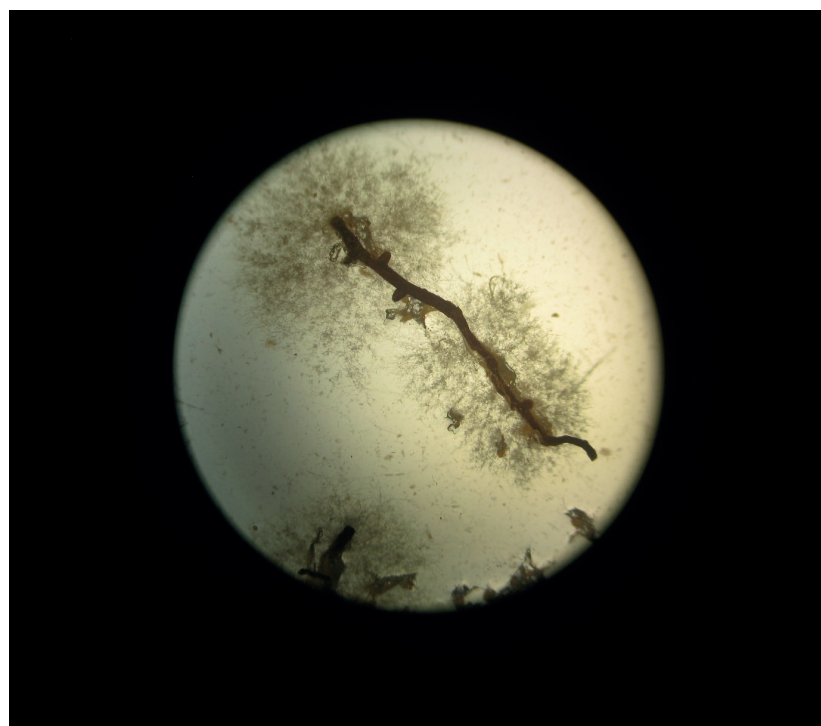

Fig. 4 Phytophthora cinnamomi isolated from infected roots of the Wollemi pine. Photo: Edward Liew, Royal Botanic Gardens and Domain Trust.

the canopy of a tree it is highly likely that the destruction of the fine root system is already in an advanced state (Jung et al., 2018).

This can make diagnosis difficult as the fine root system may well have been colonised by secondary fungi which may mask the presence of the Phytophthora species causing the disease. 
Also in 2004 Phytophthora cinnamomi was recovered from the wild population site; two plants in that population were observed to have symptoms of the disease. At a later date the related Phytophthora species, $P$. multivora, was also detected at the Wollemi pine site and shown to be potentially pathogenic (Puno et al., 2015). The most likely scenario for the introduction of the pathogen into the site was via infested soil adhering to illegal and unauthorised visitors to the site. Scientists visiting the site had recognised the importance of site hygiene and elaborate precautions were taken to ensure that they did not transport the pathogen to the site. It was recognised that this introduction was potentially catastrophic to the Wollemi pine and a number of steps were taken to minimise the impact. Seed banking and commercial horticultural production had ensured that the species was unlikely to become extinct per se and a complete ex situ representation of the population was maintained at the Australian Botanic Garden at Mount Annan in Western Sydney. Attempts were made to eradicate Phytophthora species from the site using applications of fungicides. While this resulted in a reduction in the extent of the infestation, the pathogen was still able to be recovered from the site. Current pathogen research is focused on techniques such as 'bark painting' with potassium phosphonate as a non-invasive technique to protect trees from the impact of the disease (Liew, unpublished data) (Figs $7 \& 8)$.

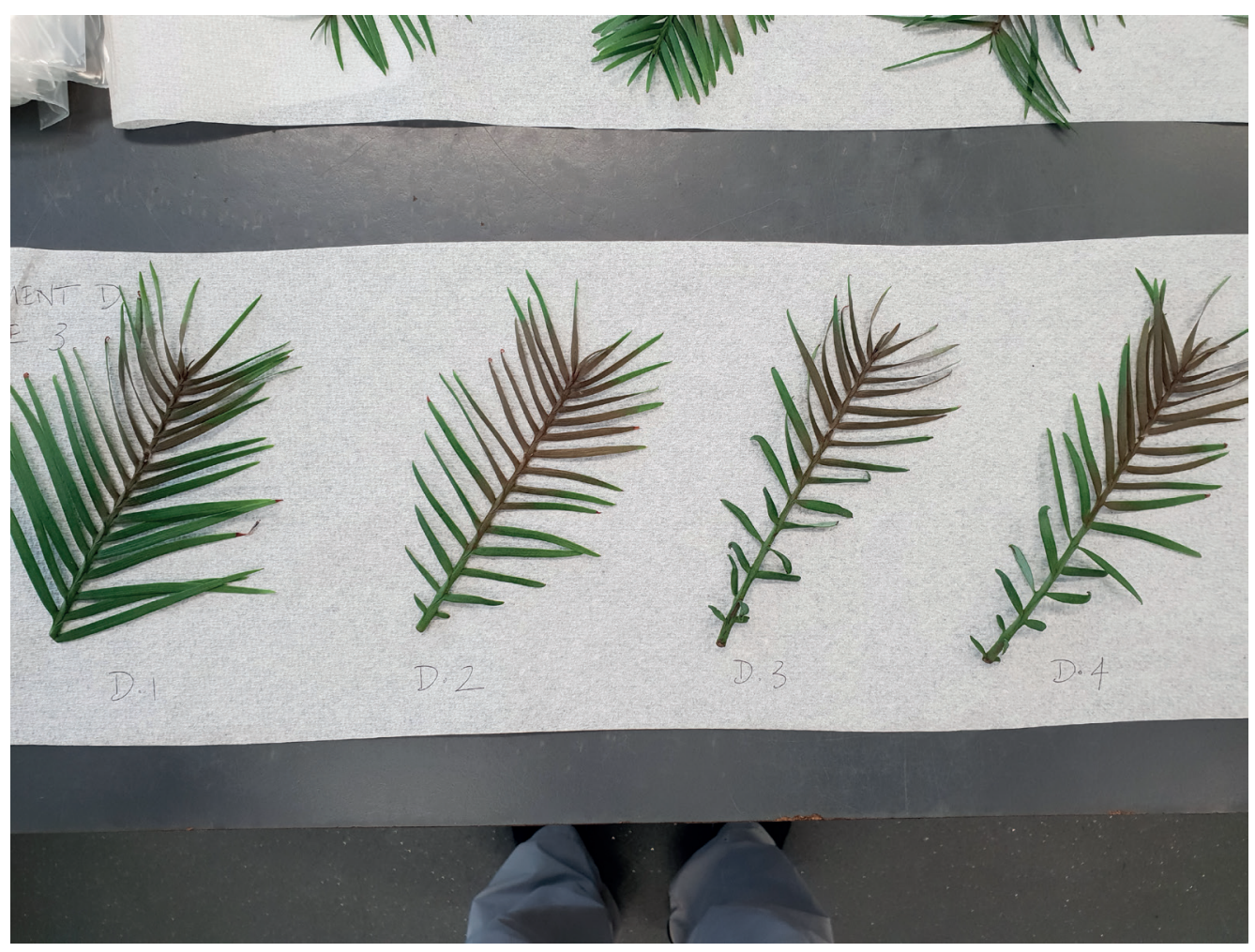

Fig. 7 Detached branch of Wollemi pine inoculated with Phytophthora cinnamomi. Photo: Edward Liew, Royal Botanic Gardens and Domain Trust. 


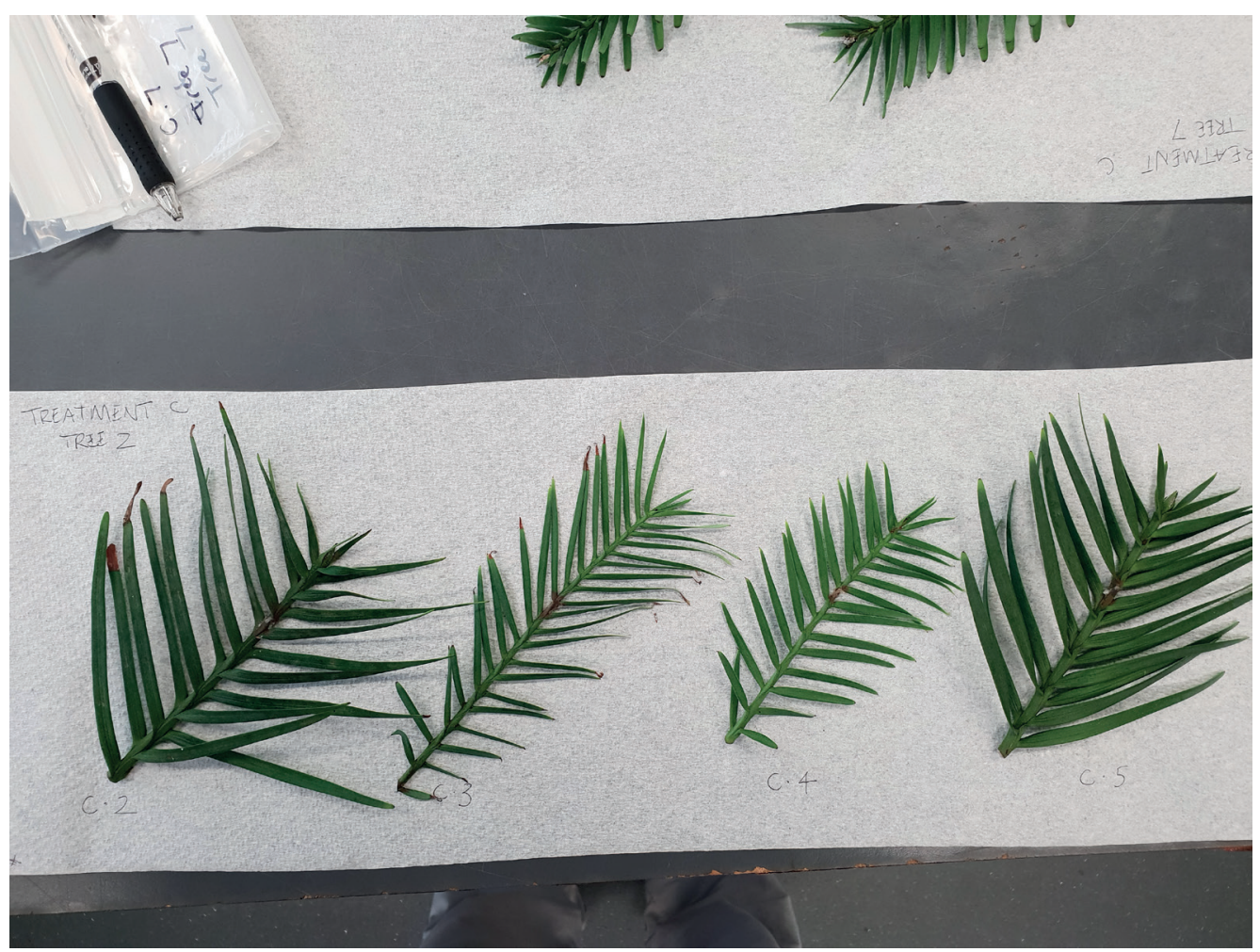

Fig. 8 Detached branch of Wollemi pine, control for bioassay with Phytophthora cinnamomi. Photo: Edward Liew, Royal Botanic Gardens and Domain Trust.

It is recognised, however, that there is a possibility of the disease winning, and recent efforts have focused on the establishment of a translocated population in a location shown to be free of the pathogen and remote enough to deter visitation and consequently less likely to have the pathogen introduced. Equally critically important is to ensure that the translocated population of the plant is completely free of the pathogen (Fig. 9) so that an accidental incursion of the pathogen does not occur which would negatively impact the translocated population and the incipient vegetation at the site. An experimental translocation has been attempted with promising results (Rigg et al., 2016; Zimmer et al., 2016) and the search is now on to find an appropriate location to establish a translocated population.

\section{Managing Phytophthora in a botanic garden}

The most effective method of control of diseases caused by Phytophthora species depends on preventing introduction and spread of the pathogen. It is critical that all efforts are made to ensure that the pathogen is not introduced into a site and that if it is present steps are made to ensure that it is not moved around that site, or to new sites. The most likely means by which Phytophthora species will be introduced to a location is via soil that contains spores or other propagules. This can be through the 


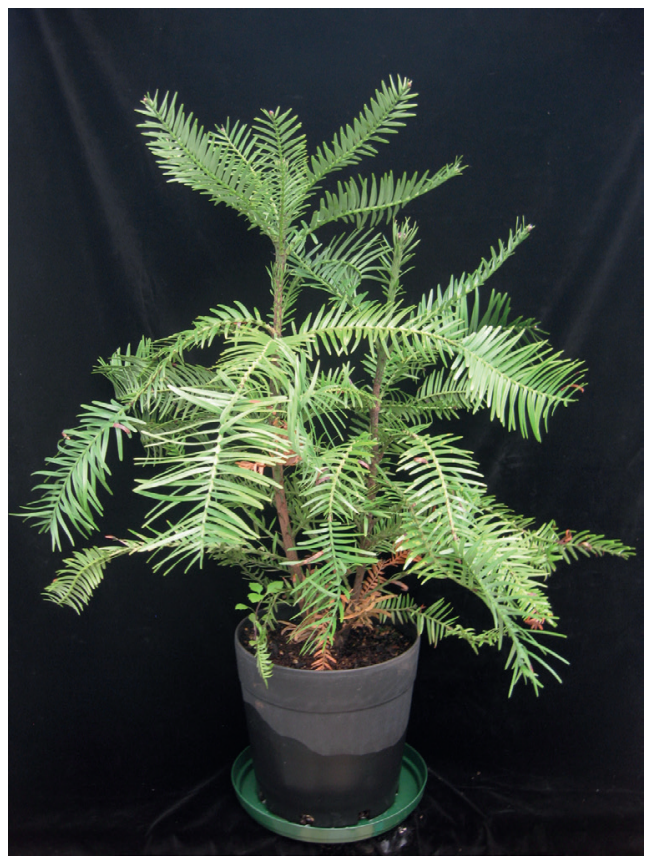

Fig. 9 Juvenile healthy Wollemi pine. Photo: Edward Liew, Royal Botanic Gardens and Domain Trust.

use of infected plant material, contaminated soil or potting material, or in soil clinging to tools, footwear or the tyres of cars, trucks or other machinery.

There are limited fungicides that are registered for use on ornamental plants to control phytophthora root rot. Of these, potassium phosphonate offers the most promising control of a number of diseases caused by Phytophthora species (Hardy et al., 2001; Scott et al., 2015).

\section{Preventing the disease}

The most effective way to prevent phytophthora root rot in botanic gardens is by preventing the introduction of the pathogen to the site. Consequently, horticultural hygiene is critical and it is important to ensure that garden staff returning from field work in natural ecosystems, or from nurseries, carefully disinfest footwear, tools and vehicles to minimise contamination.

Although thought to be widespread in many areas, Phytophthora species are not ubiquitous and the potential to introduce infection into new sites and into new hosts remains significant. Soil or mud on footwear, clothing, vehicles, tyres, equipment and tools provides the ideal medium to spread Phytophthora species and hygiene protocols (Box 1) seek to limit the human-assisted spread of Phytophthora species. Nursery stock can be an important vector for introduction of these pathogens; Jung et al. (2016) have demonstrated that a number of Phytophthora species can be recovered from nursery material in Europe while Sims et al. (2019) document Phytophthora species findings and sanitation in restoration nurseries. The authors (unpublished data) have recovered Phytophthora species from plants from commercial nurseries in Australia.

\section{What to do if you have Phytophthora in the garden}

Knowing the distribution of the pathogen and the location of dieback sites is fundamental to effective management of Phytophthora dieback. Surveying and mapping must be undertaken before control measures are introduced so that resources are prioritised to where they are needed most and unnecessary measures are avoided. Professional advice should be sought before undertaking a survey for all Phytophthora species; however, the sampling process is relatively simple and can be undertaken without professional training. The sampling frequency, location and intensity will depend on the purpose of the survey. For example, if the survey is to determine the cause of dieback in a specific garden bed, then 


\section{Box 1 A hygiene protocol for working in botanic gardens}

- Always assume the area you are entering is free of Phytophthora species unless otherwise tested and understand that your activities have the potential to introduce Phytophthora species and consequently impact plantings for many years.

- To avoid introducing the pathogen, before entering uninfested sites remove excess soil and mud from boots, tools, gloves and small equipment and then spray with a recommended disinfectant (Fig. 10).

- Recommended disinfectant products include:

- Non-corrosive disinfectants such as Coolacide ${ }^{\oplus}$, Phytoclean ${ }^{\circledast}$ or Biogram ${ }^{\circledast}$ for cleaning footwear, tools, tyres, machinery and other items in contact with soil.

- $\quad 70 \%$ methylated spirits in spray bottle for personal use.

- Sodium hypochlorite 1\% (bleach), which is very effective but can damage clothing and degrades rapidly in light.

- To avoid spreading Phytophthora species, when leaving infested sites remove excess soil and mud from boots, tools, gloves and small equipment and then spray with methylated spirits or disinfectant until run-off is clear.

- Sequence works so they begin in non-infested sites and then move on to areas that are known to be infested.

- It is highly recommended to use coloured tape to label tools when working in infested sites. Remove tape once tools have been cleaned.

- Avoid working on a site if the soil is saturated and mud is likely to adhere to footwear and tools.

- Avoid unnecessary soil disturbance.

- Do not import plants unless they are from accredited nurseries that implement effective hygiene practices. Place imported plants in a quarantine area for a period of time (up to 4-6 weeks) to observe if symptoms develop or to test for the presence of the pathogen. On infested sites, plant only species known to be resistant to Phytophthora if possible.

- Deter visitors from coming into contact with soil at infested areas through the use of barriers and signage (Fig. 11).

- Use mulch sourced from disease-free trees and taken from at least $1 \mathrm{~m}$ above ground level.

- Never import soil or gravel unless it is certified to be free of Phytophthora by a plant disease diagnostic laboratory.

- All materials removed from an infested site must be bagged and taken to landfill.

- Divert run-off water away from uninfested sites, to the lowest point on the landscape or into natural watercourses. Try to avoid run-off from known infested sites to prevent the unintended consequence of Phytophthora spread via natural waterways.

- Incorporate sub-surface drainage (ag-pipe) and drains along the edge of the uninfested areas.

\section{During garden bed construction:}

- Clean machinery and footwear before and after entering the site.

- If a site is heavily infested then machinery may have to be cleaned before leaving the site, particularly if the machinery is only operated in the local area.

- Fence off access to the site.

- Plan works so they begin in non-infested sites and then move on to infested areas

- Do not move or store materials, equipment and machinery outside the construction zone.

- Store excavated material at the construction site or move to waste depots located offsite.

- Avoid working in wet conditions. 
sampling could be undertaken at the site in question, plus additional sampling at a similar 'control' site which has not exhibited symptoms.

\section{Identifying potentially diseased areas}

Areas of potential Phytophthora infestation can be identified by the presence of dieback symptoms. Individual plants may exhibit symptoms such as chlorosis of leaves, poor crown development, dieback of major branches, stunted growth and shallow root systems. Signs of dieback may be visible in plant species that are considered susceptible.

Knowledge of susceptible indicator plants is important. For example, in the Royal Botanic Garden Sydney, Xanthorrhoea species (e.g. X. australis, X. glauca and X. resinifera) (Duncan \& Keane, 1996), Banksia serrata (Cho, 1983; McCredie et al., 1985), Telopea species (waratahs), and some Boronia and Tetratheca species can provide early notice that Phytophthora cinnamomi is active. Such plants can be considered 'indicator plants' for P. cinnamomi infection, as they are frequently among the first species to succumb to disease and they succumb relatively quickly or within months.

Once the first dieback symptoms have been detected in one plant, the surveyor should assess the surrounding area to note the general disease pattern, including how the symptoms are distributed across the site, the species and individuals affected, the topography of the site, the severity of symptoms, and other factors such as fires. Disease patterns resulting from infection by Phytophthora species will vary according to the type and number of plant species within an area, environmental factors such as topography and soil health and the length of time the site has been infested. Common

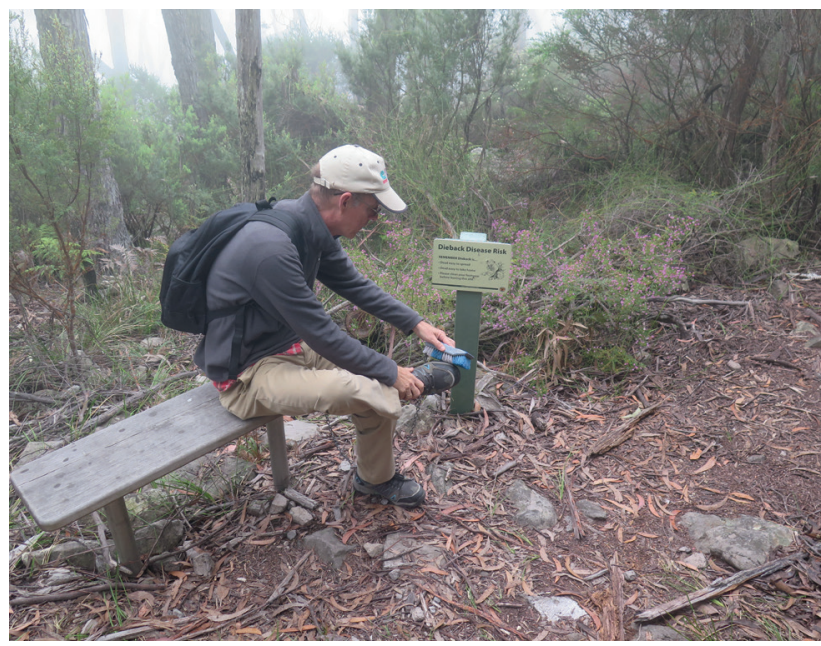

Fig. 10 Using dieback cleaning station, Mount Imlay National Park, New South Wales, Australia. Photo: Gavin Phillips, Royal Botanic Gardens and Domain Trust.

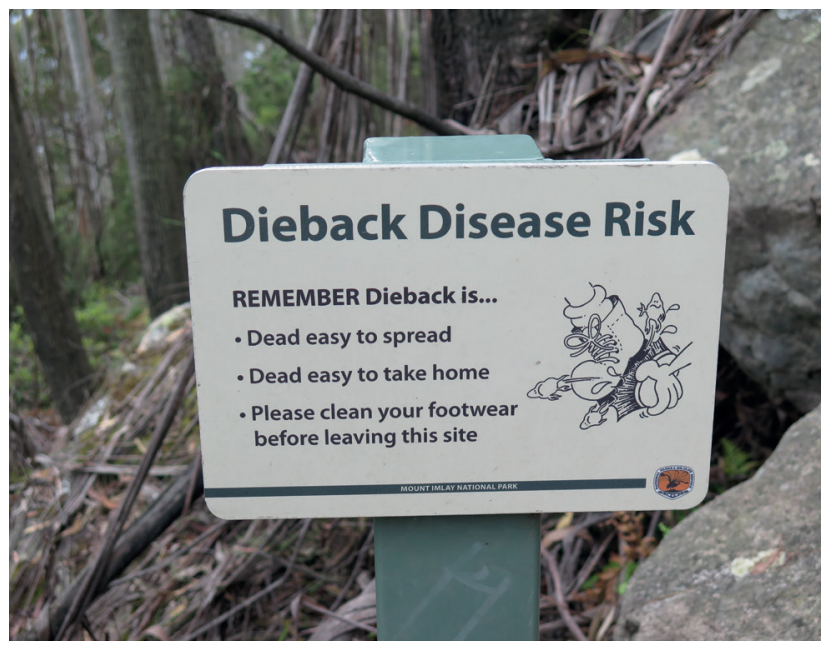

Fig. 11 Dieback signage, Mount Imlay National Park, New South Wales, Australia. Photo: Brett Summerell, Royal Botanic Gardens and Domain Trust.

distribution patterns of disease include the following:

\section{Disease fronts}

Dieback can be visually obvious in recently infested sites containing numerous susceptible species. Affected plants will exhibit an edge effect with a clear boundary 
between diseased and healthy specimens, usually occurring along contours and drainage lines. Vehicle and pedestrian tracks, construction sites, earthmoving works and picnic areas are typical introduction points for the disease into new areas and can be surveyed systematically in the absence of dieback symptoms.

\section{Dieback development and symptoms}

A disease cycle ensues once a Phytophthora species has been introduced into a garden bed. Detecting dieback may depend upon the length of time the pathogen has been present. The phases are classified as follows:

\section{Early phase}

- Chlorosis and death of numerous susceptible species occur.

- Dieback of the crown of susceptible trees may occur in 1-3 years.

- Pathogen population in roots of affected plants is high, and sampling is more likely to test positive.

\section{Mid phase}

- Loss of ground cover and increased surface erosion resulting from the death of susceptible understorey species may occur.

- Regeneration with disease-tolerant species (especially sedges and some grasses) occurs.

- Regenerated areas are out of character with nearby plant communities.

- Pathogen populations decline which may lead to false negative sampling results.

\section{Late phase}

- Specimens in which a Phytophthora species like $P$. cinnamomi has been present for many years may undergo periods of regeneration depending on their susceptibility.

- Frequently many samples may be needed to detect the pathogen in the soil, as pathogen population may be very low.

Once dieback symptoms have been detected, sampling and diagnosis is the only way to confirm the presence of a Phytophthora species. Other possible causes of dieback include nutrient run-off, other plant diseases such as armillaria root rot, soil nutrient toxicity, air pollution and drought stress. Soil compaction and root damage following construction work can also lead to dieback symptoms, whether or not Phytophthora is present.

\section{Surveying for Phytophthora}

There are two main approaches to surveying for Phytophthora, both of which are necessary for effective management of these pathogens. This includes both looking for symptom development in plants, especially known susceptible species, and sampling soil for the detection of Phytophthora species.

Systematic surveys conducted at regular intervals along paths, tracks and watercourses. This is a useful method to determine the distribution of the pathogen and to identify potential sources of infection into bushland. At least two samples per site should be taken. Each sample should consist of four soil sub-samples obtained from around individual plants.

Targeted surveys of sites showing signs of dieback, sites containing susceptible species or endangered plant communities, or after high-risk events such as fire and flood. This method provides information about the cause 
and extent of disease, the need to undertake control programmes, and the effectiveness thereof. It will also help to rule out other causes of dieback. Multiple soil samples per site should be taken as well as a sample from at least one control site.

\section{Timing of surveys}

Surveys should be conducted when soil temperatures are above $12{ }^{\circ} \mathrm{C}$ and the sub-soil is moist. This is because the pathogen is active in these conditions and false negative results are less likely to occur. Late spring and late summer are generally the best times to survey in temperate and higher-altitude areas; however, surveying can be undertaken throughout much of the year in the coastal region in the subtropics and tropics. Samples should not be taken when the soil surface is saturated as this increases the likelihood of spreading the pathogen harboured in mud on footwear and tools during the surveying process.

\section{Frequency of surveys}

Survey results can only provide a snapshot of conditions at the time they are taken. Access points such as tracks or drainage lines (watercourses) leading to sites identified as ecologically important or threatened should be surveyed for the introduction of Phytophthora cinnamomi at least once every two years or after any high-risk event, including after fire, flooding or other disturbances. Surveying may not be necessary on sites identified to be not of particular significance and not subject to any particular form of disturbance (human or natural), unless used as a control site in sampling strategy or prior to any form of construction or anticipated disturbance event.

\section{What should you do when the presence of a Phytophthora species is confirmed?}

There are limited options for dealing with a site infected with a Phytophthora species within a botanic garden. The critical point is to ensure that the potential for the pathogen to be spread to other areas of the garden is limited as much as possible. The hygiene protocols mentioned previously are the key component for this and must be implemented fully, and staff and volunteers trained and notified as soon as possible. It is also critical to ensure that visitors do not unwittingly spread the pathogen within and away from the garden, and so appropriate signage and interpretation should be considered.

In some circumstances the application of pesticides may be considered to reduce the inoculum of the pathogen and improve the resilience of the host plant. The use of potassium phosphonate, for example, has been highly effective in enhancing the resistance of infected plants to attack by Phytophthora cinnamomi in Australia.

\section{Developing a sentinel network in botanic gardens}

Botanic gardens are some of the most visited locations in most cities around the world. The Royal Botanic Garden Sydney, for example, receives over 5 million visitors per annum, a large proportion coming from overseas. Consequently it might be expected that botanic gardens would have a high potential for exposure to new incursions of pests and diseases that may 'hitch a ride' with those visitors. When combined with the diversity of the collections, favourable conditions for both plant and pest growth, there is potential for new diseases to establish at botanic gardens. The development of the International Plant 
Sentinel Network ${ }^{4}$ by Botanic Gardens

Conservation International is very welcome and provides an opportunity for more systematic detection of new incursions at high-visitation locations (see Marfleet and Sharrock, this issue). A number of priority pests and diseases are included in the programme on highly susceptible host plants grown in botanic gardens along with training in detection and regular updates in the spread of these diseases. There are opportunities in this approach to detect new incursions, detect expansion of the host range of a pathogen or record the impact of a disease on species of plants from other countries where a pathogen may not yet be detected to better inform biosecurity agencies in those countries or jurisdictions.

\section{Conclusions}

The phytophthora root rot complex is one of the most common diseases affecting perennial plants worldwide, has a huge impact on native plant communities and is one of the worst diseases to impact collections in botanic gardens. The impact of the disease can persist for months or years and the management options are very limited. As such it is critical that every step to avoid the introduction of the pathogen into gardens is taken. By the adoption of relatively simple hygiene protocols it is possible to minimise the likelihood of these diseases occurring. As such, training horticultural staff, and the broader community, about the importance of these diseases is critical, and botanic gardens are an ideal venue to do this. The recognition that botanic gardens may play an important role as sentinel locations for the early detection of both pests and diseases is overdue and welcome.

\section{References}

ARENTZ, F. \& SIMPSON, J.A. (1986). The occurrence of Phytophthora cinnamomi in Papua New Guinea with notes on its origins. Transactions of the British Mycological Society, 87: 289-295.

BULLOCK, S., SUMMERELL, B.A. \& GUNN, L.V. (2000). Pathogens of the Wollemi Pine, Wollemia nobilis. Australasian Plant Pathology, 29: 211-214.

BURGESS, T.I., SCOTT, J.K., MCDOUGALL, K.L., STUKELY, M.J.C., CRANE, C., DUNSTAN, W.A., BRIGG, F., ANDJIC, V., WHITE, D., RUDMAN, T., ARENTZ, F., OTA, N. \& ST HARDY, G.E. (2016). Current and projected global distribution of Phytophthora cinnamomi, one of the world's worst plant pathogens. Global Change Biology. doi. org/10.1111/gcb.13492.

BURGESS T.I., SIMAMORA, A.V., WHITE, D., WILLIAMS, B., SCHWAGER, M., STUKELY, M.J.C. \& HARDY G.E.ST.J. (2018). New species of Phytophthora Clade 6a: evidence for recent radiation. Persoonia, 41: 1-17.

BURGESS, T.I., WHITE, D., MCDOUGALL, K.M., GARNASC, J., DUNSTAN, W.A., CATALA, S., CARNEGIE, A.J., WORBOYS, S., CAHILL, D., VETTRAINO, A.-M., STUKELY, M.J.C., LIEW, E.C.Y. ET AL. (2017). Distribution and diversity of Phytophthora across Australia. Pacific Conservation Biology, 23: 1-13.

CHO, J.J. (1983). Variability in susceptibility of some Banksia species to Phytophthora cinnamomi and their distribution in Australia. Plant Disease, 67: 869-871.

DUDZINSKI, M.J., OLD, K.M. \& GIBBS, R.J. (1993). Pathogenic variability of Australian isolates of Phytophthora cinnamomi. Australian Journal of Botany, 41: 721-732.

DUNCAN, M.J. \& KEANE, P.J. (1996). Vegetation changes associated with Phytophthora cinnamomi and its decline under Xanthorrhoea australis in Kinglake National Park, Victoria. Australian Journal of Botany, 44: 355-369.

ERWIN, D.C. \& RIBEIRO, O.K. (1996). Phytophthora Diseases Worldwide. APS Press, St. Paul, MN.

GERRETTSON-CORNELL, L. (1986). Phytophthora 
cinnamomi in New South Wales. Forestry Commission of New South Wales, Sydney.

HARDY, G.E.ST.J., BARRETT, S. \& SHEARER, B.L. (2001). The future of phosphite as a fungicide to control the soilborne plant pathogen Phytophthora cinnamomi in natural ecosystems. Australasian Plant Pathology, 30: 133-139.

IRWIN, J.A.G., CAHILL, D.M. \& DRENTH, A. (1995). Phytophthora in Australia. Australian Journal of Agricultural Research, 46: 1311-1337.

JONES, W.G., HILL, K.D. \& ALLEN, J.M. (1995). Wollemia nobilis, a new living genus and species in the Araucariaceae. Telopea, 6: 173-176.

JUNG, T., ORLIKOWSKI, L., HENRICOT, B., ABAD-CAMPOS, P., ADAY, A.G., AGUÍN CASAL, O., BAKONYI, J., CACCIOLA, S.O., CECH, T., CHAVARRIAGA, D., CORCOBADO, T., CRAVADOR,

A. ET AL. (2016). Widespread Phytophthora infestations in European nurseries put forest, semi-natural and horticultural ecosystems at high risk of Phytophthora diseases. Forest Pathology, 46: 134-163.

JUNG, T., PÉREZ-SIERRA, A., DURÁN, A., MORTA JUNG, M., BALCI, Y. \& SCANU, B. (2018). Canker and decline diseases caused by soil- and airborne Phytophthora species in forests and woodlands. Persoonia, 40: 182-220.

MARTIN, F.N. \& COFFEY, M.D. (2012).

Mitochondrial haplotype analysis for differentiation of isolates of Phytophthora cinnamomi.

Phytopathology, 102: 229-239.

MCCREDIE, T.A., DIXON, K.W.D. \&

SIVASITHAMPARAM, K. (1985). Variability in the resistance of Banksia L.f. species to Phytophthora cinnamomi Rands. Australian Journal of Botany, 33: 629-637.

MCDOUGALL, K.L., HOBBS, R.J. \& HARDY, G.E.ST.J. (2002). Floristic and structural differences between Phytophthora infested and adjoining uninfested vegetation in the northern jarrah (Eucalyptus marginata) forest of Western Australia. Australian Journal of Botany, 50: 277-288.

MCDOUGALL, K.L. \& SUMMERELL, B.A. (2003). The impact of Phytophthora cinnamomi on the flora and vegetation of New South Wales - a re-appraisal. In: MCCOMB, J.A., HARDY, G.E.ST.J. \& TOMMERUP, I.C. (eds), Phytophthora in Forests and Natural Ecosystems. 2nd International IUFRO Working Party, 7 February 2009 Meeting, Albany, Western Australia, October 2001. Murdoch University Print, Murdoch, pp. 49-56.

MCDOUGALL, K.L., SUMMERELL, B.A., COBURN, D. \& NEWTON, M. (2003). Phytophthora cinnamomi causing disease in subalpine vegetation in New South Wales. Australasian Plant Pathology, 32: 113-115.

OFFORD, C.A., PORTER, C., MEAGHER, P. \& ERRINGTON, G. (1999). Sexual reproduction and early plant growth of the Wollemi pine (Wollemia nobilis), a rare and threatened Australian conifer. Annals of Botany, 84: 1-9.

PEAKALL, R., EBERT, D., SCOTT, L., MEAGHER, P. \& OFFORD, C. (2003). Comparative genetic study confirms exceptionally low genetic variation in the ancient and endangered relictual conifer, Wollemia nobilis (Araucariaceae). Molecular Ecology, 12: 2331-2343.

PODGER, F.D. \& BROWN, M.J. (1989). Vegetation damage caused by Phytophthora cinnamomi on disturbed sites in temperate rainforest in western Tasmania. Australian Journal of Botany, 37: 443-480.

PRATT, B.H. \& HEATHER, W.A. (1973). The origin and distribution of Phytophthora cinnamomi Rands in Australian native plant communities and the significance of its association with particular plant species. Australian Journal of Biological Science, 26: 559-573.

PUNO, V.I., LAURENCE, M.H., GUEST, D.I. \& LIEW, E.C.Y. (2015). Detection of Phytophthora multivora in the Wollemi Pine site and pathogenicity to Wollemia nobilis. Australasian Plant Pathology, 44: 205-215.

RIGG, J.L., OFFORD, C.A., ZIMMER, H., ANDERSON, I.C., SINGH, B.C. \& POWELL, J.R. (2016). Conservation by translocation: establishment of Wollemi pine and associated microbial communities in novel environments. Plant and Soil. doi.org/10.1007/s11104-016-3010-2.

SCARLETT, K., DANIELS, R., SHUTTLEWORTH, L.A., ROY, B., BISHOP, T.F.A. \& GUEST, D.I. (2015). Phytophthora in the Gondwana Rainforests of Australia World Heritage Area. Australasian Plant Pathology, 44: 335-348.

SCOTT, P.M., BARBER, P.A. \& HARDY, G.E.S.

(2015). Novel phosphite and nutrient application 
to control Phytophthora cinnamomi disease. Australasian Plant Pathology, 44: 431. doi. org/10.1007/s13313-015-0365-4.

SCOTT, P.M., BURGESS, T.I., BARBER, P.A., SHEARER, B.L., STUKELY, M.J.C., G.E.ST.J. HARDY \& JUNG, T. (2009). Phytophthora multivora sp. nov., a new species recovered from declining Eucalyptus, Banksia, Agonis and other plant species in Western Australia. Persoonia, 22: 1-13.

SHEARER, B.L. \& TIPPETT, J.T. (1989). Jarrah Dieback: the dynamics and management of Phytophthora cinnamomi in the Jarrah (Eucalyptus marginata) forest of South-western Australia. Research Bulletin No. 3. CALM.

SIMS, L., TJOSVOLD, S., CHAMBERS, D. \& GARBELOTTO, M. (2019). Control of Phytophthora species in plant stock for habitat restoration through best management practices. Plant
Pathology, 68, 196-204. doi.org/10.1111/ ppa.12933.

TSAO, P.H. (1990). Why many phytophthora root rots and crown rots of tree and horticultural crops remain undetected. Bulletin OEPP/EPPO Bulletin, 20: 11-17.

WESTE, G. (1994). Impact of Phytophthora species on native vegetation in Australia and Papua New Guinea. Australasian Plant Pathology, 23, 190-209.

WESTE, G. \& VITHANAGE, K. (1979). Survival of chlamydospores of Phytophthora cinnamomi in several non-sterile, host free forest soils and gravels at different soil water potentials. Australian Journal of Botany, 27, 1-9.

ZIMMER, H.C., OFFORD, C.A., AULD, T.D. \&

BAKER, P.J. (2016). Establishing a new population of a shade-tolerant rainforest conifer. Plos 1 doi:10.1371/journal.pone.0157559. 